\title{
Awareness of E-learning amongst medical teachers
}

\author{
Sikandarbanu Yerolavi ${ }^{1 *}$, Rashmi Patil ${ }^{2}$, Praveen Iyer ${ }^{3}$ \\ ${ }^{1}$ Associate Professor, ${ }^{2,3}$ Additional Professor, Department of Anatomy, Seth GS Medical College and KEM Hospital, Parel, Mumbai, \\ Maharashtra, INDIA. \\ Email: banusy@gmail.com
}

Abstract Background: E-learning refers to the use of internet technologies to deliver a broad array of solutions that enhance knowledge and performance. In parallel with the technology revolution of the past decades, e-learning has become an important component in many medical curriculum. Therefore, research on this topic is necessary as faculty perceptions and experiences are fundamental to their adoption of pedagogical change. Thus it was planned to study awareness of elearning amongst medical faculty. Objectives: To estimate the awareness of e-learning amongst medical teachers. To find difficulties faced by teachers for providing e-learning resources to students. To study the awareness of different packages of e-learning used/heard. Method: Fifty preclinical medical teachers from government and municipal medical colleges in Mumbai were included in the study. Permission from Institutional Ethics Committee was taken. A questionnaire was prepared taking into consideration the objectives. The questionnaire containing open and close-ended questions were validated. This validated questionnaire was administered to the participants after taking their informed consent. The completed questionnaires were collected numbered and statistically analysed. Results: In this study, 94\% of faculty members were aware of mode of e- learning resources as reference in teaching material. This proves the fact that faculty, administrators, and learners find that multimedia e-learning enhances both teaching and learning. Majority of faculty members are aware of e-learning resources and are using the same in their teaching. Faculty members were aware about availability of basic e- learning resources like PowerPoint presentations, videos and audio clips etc, but unaware about others like LMS, podcast etc. This suggests requirement of advance training of all faculty members in same. Our study illustrates the gap between faculty perceptions and use of e-learning resources and highlights the needs for institutional support and strategies to bridge the gap.

Key Word: E-learning, medical teacher.

*Address for Correspondence:

Dr. Sikandarbanu Yerolavi, Associate Professor, Department of Anatomy, Seth GS Medical College and KEM Hospital, Parel, Mumbai -12 Email: banusy@gmail.com

Received Date: $26 / 10 / 2020$ Revised Date: 02/01/2020 Accepted Date: 30/01/2020

DOI: https://doi.org/10.26611/10011431

This work is licensed under a Creative Commons Attribution-NonCommercial 4.0 International License. (cc)) BY-NC

\begin{tabular}{|l|l|}
\hline \multicolumn{2}{|c|}{ Access this article online } \\
\hline Quick Response Code: & Website: \\
& www.medpulse.in \\
& \\
\hline
\end{tabular}

\section{INTRODUCTION}

E-learning refers to the use of Internet technologies to deliver a broad array of solutions that enhance knowledge and performance ${ }^{1}$. In the past few decades, changes in health care delivery and advances in medicine have increased demands on academic faculty, resulting in less time for teaching than has previously been the case ${ }^{2-3}$. In parallel with the technology revolution of the past decades, e-learning have become an important component in many medical curriculum. An increasing number of elearning tools has been developed and is now employed in various settings according to the subject and intentions of the educational endeavor. Today's medical students have grown up mostly in an already technologically supported learning environment. In the era of computers and hand-held devices, teaching and learning have gone far beyond the textbooks, venturing into various components of the digital world. The United Nations and WHO have acknowledged e-learning as a useful tool in addressing educational needs in healthcare workers, 
especially in developing countries ${ }^{4}$. The integration of elearning in medical education is the need of the hour. Faculty, administrators, and learners find that multimedia e-learning enhances both teaching and learning. These advantages can be categorized as targeting either learning delivery or learning enhancement. Blended learning, a fairly new term in education but a concept familiar to most educators, is an approach that combines e-learning technology with traditional instructor-led training, where, for example, a lecture or demonstration is supplemented by an online tutorial ${ }^{6}$. There have been several studies on medical students' positive perceptions and extensive use of e-learning resources ${ }^{2-3}$, but research on faculty perceptions and use of these resources has been limited. Therefore, research on this topic is necessary as faculty perceptions and experiences are fundamental to their adoption of pedagogical change. Herein, we investigated awareness of e-learning amongst medical faculty

- An increasing number of e-learning tools has been developed and is now employed in various settings according to the subject and intentions of the educational endeavour

- The United Nations and WHO have acknowledged elearning as a useful tool in addressing educational needs in healthcare workers, especially in developing countries ${ }^{4}$.
- In the past few decades, changes in health care delivery and advances in medicine have increased demands on academic faculty, resulting in less time for teaching than has previously been the case ${ }^{2,3}$.

\section{OBJECTIVES}

- To estimate the awareness of e-leaning amongst medical teachers

- Difficulties faced by teachers for providing e-learning resources to students

- To study the awareness of different packages used/heard of e-learning

\section{METHODOLOGY}

- Hundred preclinical medical teachers from government and BMC Medical Colleges in Mumbai has been included in the study. Permission from institutional ethics committee has been taken.

- A questionnaire was prepared taking in consideration of objectives. The questionnaire containing open and close-ended questions were validated. This validated questionnaire were administered to the participants after taking their informed consent. The completed questionnaire were collected and numbered.

\begin{tabular}{|c|c|c|c|c|}
\hline Sr.No. & Points & \multicolumn{3}{|c|}{ Comments } \\
\hline 1 & $\begin{array}{c}\text { Have you heard of mode of e- learning resources as references in } \\
\text { teaching materials? }\end{array}$ & \multirow{2}{*}{\multicolumn{2}{|c|}{$\begin{array}{l}\text { Yes }(94 \%) \\
\text { Yes }(74 \%)\end{array}$}} & No $(6 \%)$ \\
\hline 2 & $\begin{array}{l}\text { If yes, have you used e-learning resources as references in teaching } \\
\text { materials? }\end{array}$ & & & No (26) \\
\hline $\mathrm{i}$ & If yes, how frequently it is used? & $\begin{array}{c}\text { For } 1 \\
\text { class(3\%) }\end{array}$ & $2-5$ classes $(22 \%)$ & $>5$ classes $(44 \%)$ \\
\hline iii & $\begin{array}{l}\text { What are the difficulties faced by you for providing e-learning } \\
\text { resources to students? }\end{array}$ & $\begin{array}{c}\text { No } \\
\text { availability } \\
\text { of } \\
\text { internet } \\
(46 \%)\end{array}$ & $\begin{array}{l}\text { nvenience to } \\
\text { use(10) }\end{array}$ & $\begin{array}{l}\text { No need for non-traditional } \\
\text { resources }(6 \%)\end{array}$ \\
\hline 3 & $\begin{array}{l}\text { Have you used e-learning resources as pre-class assignments for } \\
\text { students? }\end{array}$ & \multicolumn{2}{|l|}{ Yes (20) } & No $(68 \%)$ \\
\hline 4 & $\begin{array}{l}\text { Have you used any modes of e-learning during routine teaching for } \\
\text { undergraduate students? }\end{array}$ & \multicolumn{2}{|l|}{ Yes (68\%) } & No $(24 \%)$ \\
\hline 5 & If yes how frequently it is used? & For 1 class(6\%) & $\begin{array}{c}2-5 \\
\text { classes( } 22 \%)\end{array}$ & $>5$ classes $(28 \%)$ \\
\hline 6 & Do you use PowerPoint presentations for routine lectures? & \multicolumn{2}{|l|}{ Yes $(90 \%)$} & No $(8 \%)$ \\
\hline 7 & $\begin{array}{l}\text { Do you use audio/video clips for teaching undergraduate students } \\
\text { for cognitive learning? }\end{array}$ & \multicolumn{2}{|l|}{ Yes(82\%) } & No(12\%) \\
\hline 8 & $\begin{array}{c}\text { Are you aware of use of podcasts, animations for teaching } \\
\text { undergraduate students for cognitive learning? }\end{array}$ & \multicolumn{2}{|l|}{ Yes (64\%) } & No $(30 \%)$ \\
\hline 9 & $\begin{array}{c}\text { Are you aware of Audio-visual demonstration of procedures, } \\
\text { diagnostics and interventions for undergraduate training in } \\
\text { psychomotor domain? }\end{array}$ & \multicolumn{2}{|l|}{ Yes $(80 \%)$} & No (16\%) \\
\hline 10 & $\begin{array}{l}\text { Have you used/heard of videos of scenarios depicting good and } \\
\text { bad communication-skills, role-plays and counselling sessions, and } \\
\text { self-recordings for training in affective domain? }\end{array}$ & \multicolumn{2}{|l|}{ Yes (40\%) } & No $(42 \%)$ \\
\hline
\end{tabular}




\begin{tabular}{|c|c|c|c|c|c|}
\hline Sr. No & Questions & \multicolumn{3}{|c|}{ Comments of participants } & No comments \\
\hline 1 & $\begin{array}{l}\text { Have you heard of mode of e- learning } \\
\text { resources as references in teaching materials? }\end{array}$ & Yes (94\%) & & $(6 \%)$ & \\
\hline 2 & $\begin{array}{l}\text { If yes, have you used e-learning resources as } \\
\text { references in teaching materials? }\end{array}$ & Yes (74\%) & & (26) & \\
\hline $\mathrm{i}$ & If yes, how frequently it is used? & For 1 class(3\%) & $2-5$ classes $(22 \%)$ & $>5$ classes $(44 \%)$ & $31 \%$ \\
\hline iii & $\begin{array}{l}\text { What are the difficulties faced by you for } \\
\text { providing e-learning resources to students? }\end{array}$ & $\begin{array}{l}\text { No availability of } \\
\text { internet (46\%) }\end{array}$ & $\begin{array}{l}\text { Inconvenience to } \\
\text { use(10\%) }\end{array}$ & $\begin{array}{l}\text { No need for non- } \\
\text { traditional resources(6\%) }\end{array}$ & $38 \%$ \\
\hline 3 & $\begin{array}{c}\text { Have you used e-learning resources as pre-class } \\
\text { assignments for students? }\end{array}$ & Yes (20\%) & & $(68 \%)$ & $12 \%$ \\
\hline 4 & $\begin{array}{l}\text { Have you used any modes of e-learning during } \\
\text { routine teaching for undergraduate students? }\end{array}$ & Yes $(68 \%)$ & & $(24 \%)$ & $8 \%$ \\
\hline 5 & If yes how frequently it is used? & For 1 class $(6 \%)$ & $2-5$ classes $(22 \%)$ & $>5$ classes $(28 \%)$ & $44 \%$ \\
\hline
\end{tabular}

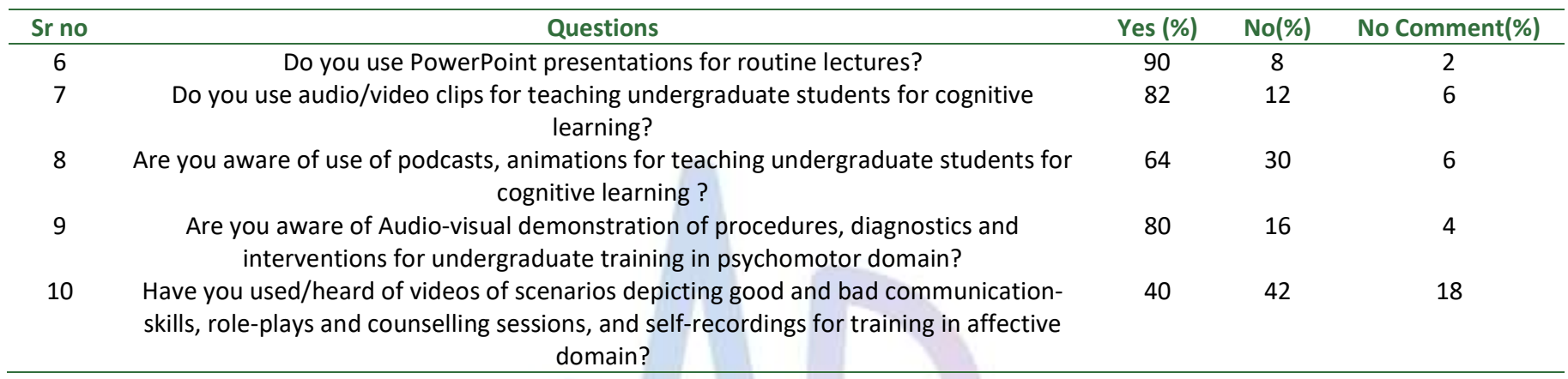

\section{DISCUSSION}

In this study $94 \%$ of faculty members were aware of mode of e- learning resources as reference in teaching material. This proves the fact that Faculty, administrators, and learners find that multimedia e-learning enhances both teaching and learning. These advantages can be categorized as targeting either learning delivery or learning enhancement ${ }^{5} 74 \%$ faculty members used elearning resources as references in teaching material and $26 \%$ haven't used. $44 \%$ faculty used e-learning resource as reference for more than 5 classes, $22 \%$ used for $2-5$ classes and 3\% used for one class. 50\% faculty faced difficulty for providing e-learning resources to students due to non availability of internet, $10 \%$ feel inconvenience to use and 5\% feels there is no need for non-traditional resources. 20\% faculty did not face any difficulty for providing e-learning sources to students. $68 \%$ faculty used various modes of e-learning during routine teaching for undergraduate students while $24 \%$ did not use. $90 \%$ faculty uses PowerPoint presentation for routine lectures while $8 \%$ did not use. They used downloaded images, videos, animated images and YouTube videos for routine teaching. $82 \%$ faculty were aware of audio/video clips and used the same for teaching undergraduate students for cognitive learning while $12 \%$ didn't use. Most of faculty members have positive perception about e-learning and consider its useful and effective, should be used with traditional teaching.

\section{CONCLUSION}

Majority of faculty members are aware of e-learning resources and are using the same in their teaching.

Unavailability of internet/wifi services is the main difficulty faced by the faculty members for providing elearning resources to students.

Faculty members were aware about availability of basic e- learning resources like PowerPoint presentations, videos and audio clips etc, but unaware about others like LMS, podcast etc. This suggests requirement of advance training of all faculty members in same. Our study illustrates the gap between faculty perceptions and use of e-learning resources and highlights the needs for institutional support and strategies to bridge the gap.

\section{REFERENCES}

1. Rosenberg M. E-Learning: Strategies for Delivering Knowledge in the Digital Age. New York: McGraw-Hill, 2001.

2. Wentling T, Waight C, Gallaher J, La Fleur J, Wang C, Kanfer A. e-Learning: A Review of Literature 2000 〈http://learning.ncsa.uiuc.edu/papers/elearnlit.pdf .

Accessed 22 November 2005. University of Illinois National Center for Supercomputer Applications, Urbana-Champaign, IL, 2000.

3. Ozuah PO. Undergraduate medical education: thoughts on future challenges. BMC Med Educ. 2002;2:8-10.

4. MCI Vision 2015 Booklet. Medical Council of India. Available from: www.mciindia.org/tools/announcement/ 
MCI booklet.pdf. Accessed June 18, 2016. 8. Choules AP. The use of e-learning in medical education: A

5. Ruiz JG, Mintzer MJ, Leipzig RM. The impact of elearningin medical education. Acad Med. 2006; 81:20712 .

\section{Policy for Articles with Open Access:}

Authors who publish with MedPulse International Journal of Anatomy (Print ISSN: 2550-7621) (Online ISSN: 2636-4557) agree to the following terms: Authors retain copyright and grant the journal right of first publication with the work simultaneously licensed under a Creative Commons Attribution License that allows others to share the work with an acknowledgement of the work's authorship and initial publication in this journal.

Authors are permitted and encouraged to post links to their work online (e.g., in institutional repositories or on their website) prior to and during the submission process, as it can lead to productive exchanges, as well as earlier and greater citation of published work.
6. Masie E. Blended learning: the magic is in themix. In: Rossett A (ed). The ASTD ELearning Handbook. New York: McGraw- Hill, 2002:58-63. Chu LF, Chan BK. Evolution of web.

Source of Support: None Declared
Conflict of Interest: None Declared

